\title{
Association of Polymorphism -174G/C Interleukin-6 (IL-6) and Schizophrenia in Bataknese Population
}

\author{
Munawir Saragih (D), Mustafa M. Amin*(D), Elmeida Effendy (D) \\ Department of Psychiatry, Faculty of Medicine, Universitas Sumatera Utara, Medan, Indonesia
}

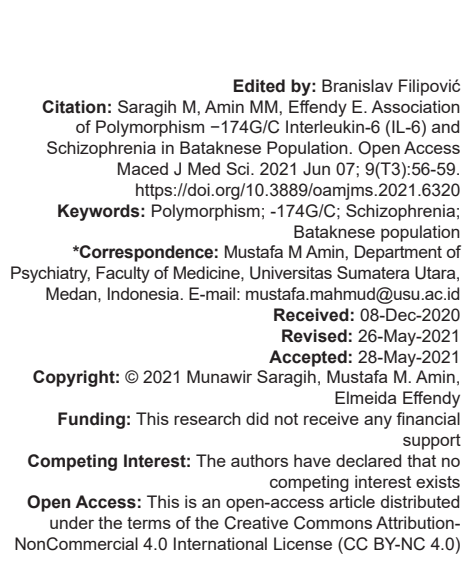

\section{Introduction}

Schizophreniaisamentaldisordercharacterized by positive symptoms (delusions, hallucinations, and disorganized speech), negative (flat affect, avolition, poor speech and language, social withdrawal), and cognitive deficits (attention deficits, impaired executive functions such as planning, abstract thinking, flexibility of rules, and inhibition of inappropriate actions and irrelevant sensory information, and short-term and longterm memory deficits). Schizophrenia was included in the top 25 diseases that were the leading causes of disability worldwide in 2013. The lifetime prevalence of schizophrenia is quite low (median 4.0/1000 people), and the worldwide prevalence range reaches 2.66.7/1000 people [1], [2].

Cytokines are modulators of immune/ inflammatory reactions and regulators for brain development. Pathological induction of cytokines in response to infections in pregnant women harms the development of the baby's nerves. One of the cytokines associated with schizophrenia is interleukin-6 (IL-6). IL-6 is known to have the function of regulating brain development, synaptic plasticity, and various behaviors related to eating, sleep, and stress. The human IL-6 gene is located on chromosome 7 (7p15-7p21) and slight variations influence the regulation of IL-6 expression in the promoter. A functional nucleotide polymorphism of $\mathrm{G}$ into a cytosine base $(\mathrm{C})$ in the $-174(-174 \mathrm{G} / \mathrm{C})$ position of the promoter has been described as proven to influence IL- 6 gene expression by modulating the binding of transcription factors such as GATA1, with several studies showing that the GG allele is associated with elevated levels of IL- 6 in the blood, this elevated level is also the most confirmed immunological feature associated with schizophrenia [3], [4], [5].

Batak tribe is one of the largest tribes in Indonesia. Based on a census from the Indonesian Central Statistics Agency in 2010, the Bataknese ranks third in the largest ethnic group in Indonesia after the Javanese and Sundanese, with the total amount of 8.3 million people, i.e., $3.6 \%$ of Indonesia's population. Batak people have a philosophy of life, principles, and at the same time as a structure and system in society called Dalihan na Tolu. This Dalihan na Tolu has a role in the Batak customary marriage laws that cannot be separated during a customary marriage ceremony 
according to the traditions of the Batak people. This system causes most Batak people to marry each other so that the purity of the population is maintained and can be applied according to Hardy-Weinberg Equilibrium [6], [7], [8], [9].

Research on gene polymorphisms in cytokines in people with schizophrenia is still minimal, Samojedny et al. in 2012 conducted a study to look for the relationship of polymorphisms of IL-2, IL-6, and tumor necrosis factor- $\alpha$ to people with paranoid schizophrenia in the polish population whose research showed the contribution of genes to these cytokines in the development of schizophrenia [5]. Due to the lack of research on this matter, then research on the association between the -174G/C IL-6 polymorphism and schizophrenia in Bataknese population needs to be done.

\section{Methods}

\section{Patient sample}

This study uses a categorical comparative analysis of one-time measurement, taking subjects using non-probability sampling, consecutive sampling, and has been carried out by taking a sample of 75 people with schizophrenia from the Bataknese population from Mental Hospital Prof. dr. M. Ildrem Medan, who was diagnosed based on ICD-10 criteria, aged 18-45 years, two generations and above are Batak tribes. The exclusion criteria were a history of psychiatric disorders other than schizophrenia that were excluded with MINI ICD-10, a history of neurological diseases, endocrine disorders, and autoimmune diseases. The 75 healthy control samples from the Batak tribes around the Universitas Sumatera Utara (USU) are willing to become research subjects. Research has been carried out in the period June 2019-November 2019, an examination of DNA isolation and examination of polymerase chain reaction-restriction fragment length polymorphism (RFLP) has been conducted in the integrated laboratory of the Faculty of Medicine, University of North Sumatra.

\section{Biological studies}

Blood sampling was carried out at six ccs from the anterior cubital vein. The blood will be inserted into a vacutainer containing ethylenediaminetetraacetic acid and stored at $4-8^{\circ} \mathrm{C}$ until DNA isolation is carried out. The method used for DNA isolation is salting out. After that, the RFLP was carried out with the Nlalll enzyme and as for the oligonucleotide primers for $-174 \mathrm{G} / \mathrm{C}$ IL-6 (forward): 5 'ATGCCAAGTGCTGAGTCACTA 3', and (reverse): 5'TCGAGGGCAGAATGAGCCTC 3'. A total of 150 bands of agarose gel electrophoresis were analyzed. The reading of the results was carried out in accordance with a study conducted by Lagmay et al. [10], [11]

\section{Statistical analysis}

Analysis of the data collected was carried out using a statistical package for service solution (SPSS ver 22) software program. Categorical variables are represented by $n$ (\%), numerical variables of a normal distribution are expressed as mean \pm standard deviations, and numerical variables of abnormal distribution are presented with median values (minimum-maximum value). If the $\chi^{2}$ conditions are met, a Chi-square test will be performed to see differences in alleles and genotypes, and if the $\chi^{2}$ conditions are not met, the Fisher's test will be conducted.

\section{Results}

The characteristics of the participants are shown in Table 1. There were no statistically significant differences in sex $(p=0.71)$ between the groups of Batak tribes, with healthy controls and men being the most participants. There was a statistically significant difference in age $(p=0.001)$ and BMI ( $p=0.019$ ) between the ODS group of the Batak tribe and healthy controls. Median pain onset and mean length of illness and total PANSS score can be seen in Table 1.

Table 1: Demographic characteristic

\begin{tabular}{|c|c|c|c|}
\hline \multirow[t]{2}{*}{ Variable } & \multicolumn{2}{|l|}{ Group } & \multirow[t]{2}{*}{$p$-value } \\
\hline & $\begin{array}{l}\text { Bataknese population with } \\
\text { Schizophrenia }(n=75)\end{array}$ & $\begin{array}{l}\text { Healthy control } \\
(n=75)\end{array}$ & \\
\hline \multicolumn{4}{|l|}{ Gender } \\
\hline Male & $53(70.7 \%)$ & $56(70.9 \%)$ & \\
\hline Female & $22(29.3 \%)$ & $19(24.1 \%)$ & $0.71^{*}$ \\
\hline Age & $36.00(22.00-45.00)$ & $29.00(18.00-45.00)$ & $0.001^{* *}$ \\
\hline BMI & $21.34 \pm 2.24$ & $22.07 \pm 1.42$ & $0.019^{\star \star \star}$ \\
\hline Onset of IIIness ${ }^{a}$ & $25.00(20.00-35.00)$ & - & \\
\hline Duration of Illness ${ }^{a}$ & $9.83 \pm 4.18$ & - & \\
\hline PANSS Total Score ${ }^{a}$ & $97.95 \pm 8.83$ & - & \\
\hline
\end{tabular}

In the $-174 \mathrm{G} / \mathrm{C}$ IL-6 polymorphism, there were significant differences statistically in alleles and genotypes between the Bataknese population with schizophrenia and the healthy control group $(p<0.001$ in both alleles and genotypes). The odds ratio (OR) values were obtained 13,245 in the alleles and 35,821 in the genotype. This means the Bataknese population with schizophrenia has the possibility (Odds) having schizophrenia 13.2 times based on alleles and 35,821 times based on genotype compared to the healthy control group. OR values above one mean polymorphism of $-174 \mathrm{G} / \mathrm{C}$ IL-6 is a risk factor for schizophrenia statistically (Table 2). 
Table 2: Differences in the distribution of alleles and genotype -174G/C IL-6 polymorphisms between Bataknese population with schizophrenia and healthy controls

\begin{tabular}{lllll}
\hline Variable & Group & p-value & OR $(95 \% \mathrm{Cl})$ \\
\cline { 2 - 3 } & $\begin{array}{l}\text { Bataknese Population with } \\
\text { Schizophrenia }(\mathrm{n}=75)\end{array}$ & $\begin{array}{l}\text { Healthy } \\
\text { Controls } \\
(\mathrm{n}=75)\end{array}$ & & \\
\hline $\begin{array}{lllll}\text { Alleles -174G/C } \\
\text { G }\end{array}$ & $\begin{array}{l}143(95.3 \%) \\
\text { C }\end{array}$ & $\begin{array}{l}91(60.7 \%) \\
59(39.3 \%)\end{array}$ & $<0.001$ & 13.245 \\
Genotype -174G/C & & & $(5.796-30.266)$ \\
GG & $68(90.7 \%)$ & $16(21.3 \%)$ & $<0.001$ & 35.821 \\
GC & $7(9.3 \%)$ & $59(78.7 \%)$ & & $(13.796-93.012)$ \\
CC & $0(0.0 \%)$ & $0(0.0 \%)$ & & \\
\hline OR: Odds ratio. & & & &
\end{tabular}

\section{Discussion}

Genetic variations describe genetic differences that occur naturally between individuals of the same species. This variation allows the flexibility and survival of populations in the face of changing environmental conditions. As a result, genetic variation is often seen as an advantage because it is a form of preparation for the unexpected. One example of genetic variation is polymorphism; several factors influence genetic variation, including marital patterns, genetic drift, physical distribution, and migration. The genetic variation that occurs due to the above factors can cause differences in the results of studies conducted on various populations and ethnicities [7].

The study results obtained at $-174 \mathrm{G} / \mathrm{C}$ IL-6 polymorphism is that there are significant differences with this polymorphism as a risk factor for schizophrenia in the Bataknese population, this study is in accordance with studies conducted by Zakharyan et al. [12] that report there are significant differences were found $(p=0.003)$ between the frequency of GG genotypes and GC + $\mathrm{CC}$ genotypes appearing in the Bataknese population with schizophrenia or the control group. Different from studies obtained by Samojedny et al. [5] that found the exact opposite of these studies. As for other studies conducted in schizophrenic patients, it is still very limited so that not many conclusions have been obtained from previous studies. As for the International HapMap Consortium that conducts all research about single nucleotide polymorphism (SNP) was reported that this polymorphism tends to be polymorphic in Caucasian populations, while in Asian and African populations, it tends to be monomorphic (for $\mathrm{G}$ alleles). This might be one of the causes of the striking difference in genotype frequency between this study and the study conducted by Zakharyan et al. and Samojedny et al. [12]

Some hypotheses suggest that schizophrenia is an inherited disorder. Early research on schizophrenia was dominated by twin, family, and adoption studies. At present, linkage studies and genome-wide associations have identified areas of chromosomes and genetic variants, both inherited and unedited, that are associated with an increased risk of this disorder.
The differences in the results of this study are different from other studies that can be caused by differences in the population where differences in polymorphism are related to population vulnerability to disease. The change in polymorphism will continue to be inherited so that the frequency of polymorphisms in each population can be different [7].

Few studies report an association between the $-174 \mathrm{G} / \mathrm{C}$ polymorphism and schizophrenia that make it challenging to conclude initial studies where little supporting data to draw conclusions from this study. Therefore, this becomes a limitation of this study so that further research is needed from different tribes and populations. Another limitation of the present study is a relatively small sample size ( 75 patients and 75 healthy controls).

\section{Conclusions}

There is an association of $-174 \mathrm{G} / \mathrm{C}$ polymorphism and schizophrenia in Bataknese population. We also conclude that $-174 \mathrm{G} / \mathrm{C}$ polymorphism may be one of the risk factors for schizophrenia in the Bataknese population.

\section{Acknowledgments}

The authors express their gratitude to the Department of Psychiatry, Faculty of Medicine, Universitas Sumatera Utara, Indonesia and all the participants of this study.

\section{Ethics approval and consent to participate}

The Research Ethics Committee approved this study at the Faculty of Medicine, Universitas Sumatra Utara before conducting research with the letter number 722 / TGL / KEPK FK USU-RSUP HAM/2019 on August 30,2019 . All participants write and sign consent to participate before attending in this research.

\section{References}

1. Chaiyakunapruk N, Wu DB, Chiou CF, Kotirum S, Teoh SL, Chong HY. Global economic burden of schizophrenia: A systematic review. Neuropsychiatr Dis Treat. 2016;12:357-73. 
https://doi.org/10.2147/ndt.s96649

PMid:26937191

2. Robertson GS, Hori SE, Powell KJ. Schizophrenia: An integrative approach to modelling a complex disorder. J Psychiatry Neurosci. 2006;31(3):157-67.

PMid:16699601

3. Watanabe Y, Someya W, Nawa H. Cytokine hypothesis of schizophrenia pathogenesis: Evidence from human studies and animal models. Psychiatry Clin Neurosci. 2010;64(3):217-30. https://doi.org/10.1111/j.1440-1819.2010.02094.x PMid:20602722

4. Kalmady SV, Venkatasubramanian G, Shivakumar V, Gautham S, Gangadhar BN. Relationship between interleukin-6 gene polymorphism and hippocampal volume in antipsychoticnaive schizophrenia: Evidence for differential susceptibility? PLoS One. 2014;9(5):e96021. https://doi.org/10.1371/journal. pone.0096021

PMid:24787542

5. Paul-samojedny M, Owczarek A, Suchanek R, Palacz M, Filadaniłow A, Borkowska P, et al. Association of interleukin paranoid schizophrenia in a Polish population. J Neuropsychiatry Clin Neurosci. 2013;25:72-82. https://doi.org/10.1176/appi. neuropsych. 12020021

6. Hugo G. Indonesia's population: Ethnicity and religion in a changing political landscape (review). Popul Rev. 2003;42(12):45-6. https://doi.org/10.1353/prv.2004.0003

7. Nature, the Genetic Variation in a Population is Caused by
Multiple Factors; 2010. Available from: https://www.nature. com/scitable/ebooks/a-brief-history-of-genetics-definingexperiments-16570302. [Last accessed on 2020 Oct 10].

8. Sitanggang JP. Raja Napogos. Jakarta: Penerbit Jala Permata Aksara; 2010.

9. Badan Pusat Statistik. Kewarganegaraan, Suku Bangsa, Agama dan Bahasa Sehari-Hari Penduduk Indonesia: Hasil Sensus Penduduk 2010. Jakarta: Badan Pusat Statistik; 2010. https://doi.org/10.14710/nusa.13.4.579-589

10. Wilson AG, di Giovine FS, Blakemore Al, Duff GW. Single base polymorphism in the human tumour necrosis factor alpha (TNF alpha) gene detectable by Ncol restriction of PCR product. Hum Mol Genet. 1992;1(5):353. http://org.doi.10.1093/hmg/1.5.353 PMid:1363876.

11. Lagmay JP, London WB, Gross TG, Termuhlen A, Sullivan N, Axel $A$, et al. Prognostic significance of interleukin-6 single nucleotide polymorphism genotypes in neuroblastoma: Rs1800795 (promoter) and rs8192284 (receptor). Clin Cancer Res. 2009;15(16):5234-9. https://doi.org/10.1158/1078-0432. ccr-08-2953

PMid: 19671870

12. Zakharyan R, Petrek M, Arakelyan A, Mrazek F, Atshemyan S, Boyajyan A. Interleukin-6 promoter polymorphism and plasma levels in patients with schizophrenia. Tissue Antigens. 2012;80(2):136-42. https://doi org/10.1111/j.1399-0039.2012.01886.x

PMid:22571276 